Article

\title{
Socio-Ecological Controversies in the News as Trigger of a Model-Based Inquiry Instructional Sequence about the Effect of Global Warming on the Great Barrier Reef
}

\author{
M. Rut Jiménez-Liso ${ }^{1}$, Manuela González-Herrera ${ }^{1}$ and Isabel Banos-González ${ }^{2, *(1)}$ \\ 1 Sensociencia Team, CEIMAR-Universidad de Almería, 04120 Almería, Spain; mrjimene@ual.es (M.R.J.-L.); \\ caregonzalez@gmail.com (M.G.-H.) \\ 2 Departamento de Didáctica de las Ciencias Experimentales, Universidad de Murcia, 30100 Murcia, Spain \\ * Correspondence: ibbg1@um.es
}

Received: 13 May 2020; Accepted: 2 June 2020; Published: 8 June 2020

\begin{abstract}
The use of socio-ecological controversies, such as global warming, in classrooms has been suggested to increase students' awareness about complex issues, although detailed analysis of their implementation in classrooms are still scarce. This research shows a model-based inquiry approach (MBI) instructional sequence, using scientific news as a trigger, aimed at addressing a global problem on a real socio-ecological system: the effect of global warming on the Great Barrier Reef. Its implementation in a lower secondary school classroom allowed the assessment of the effectiveness of the instructional sequence designed, based on students' perception of what secondary school students have learned and felt. Results show that the MBI instructional sequence seems to have favored the mobilization of students' alternative conceptions about global warming, coral reefs, and symbiotic relationships. In addition, it contributed to increasing the students' awareness of the problem of global warming and its effects on an essential socio-ecological system, such as coral reefs.
\end{abstract}

Keywords: coral; global warming; model-based inquiry approach; scientific news; teaching proposal

\section{Introduction}

The United Nations Framework Convention on Climate Change recognized, already in 1992, the need to implement specific education and awareness programs to involve the population in the study of the problem and its consequences, as well as in adequate decision making [1]. Despite institutional efforts since then and scientific consensus on the effects of global warming [2], as well as the recent youth mobilizations demanding a future for next generations [3], students seem still unaware of their role in generating the problem and how its consequences affect them [4,5]. According to different authors, scarce scientific knowledge might limit students' argumentation skills based on evidence, which would empower them for democratic problem-solving action regarding socio-ecological issues [6,7].

Global warming (GW) is a complex problem [8], since the socio-economic and ecological drivers of this issue interact in a nonlinear fashion, characterized by their reinforcing mechanisms and time delays [9], which may represent an obstacle for an adequate understanding of the problem and, therefore, complicate the adoption of individual responsibilities [10].

From the educational arena, this situation should not leave us indifferent, among other reasons, because educators must get involved in the task of citizen activation, if we want to contribute to training responsible and capable people to participate in decision making [11]. GW is identified as an area of intersection of science and society "that result[s] in complex and often controversial issues" [12] (p. 639), which is recognized as a productive context for teaching and learning [13]. Thus, more efforts 
should be taken in order to facilitate students' understanding of controversial socio-scientific issues such as GW. In this sense, some authors have suggested the use of educational approaches based on their alternative conceptions and engaging students in scientific discourse [5]. So it will be necessary to diagnose the students' previous conceptions and to plan activities in which those ideas about complex problems may come into conflict, fostering learning that helps students understand the world, to make informed decisions, and to act as a community in a responsible, sustainable, and democratic manner, to face present-day and future problems [7]. Nonetheless, we must be aware that students do not automatically transform their beliefs when receiving new information which is more in accordance with scientific knowledge [14].

Numerous research studies have diagnosed and described students' alternative conceptions about all kinds of science topics $[15,16]$. Alternative conceptions and myths about socio-ecological issues also have a long history $[4,17,18]$. In the vast majority of research based on a diagnosis of conceptions, students' ideas have been collected by using well-constructed and validated questionnaires-very useful for research, but less appropriate or formative for the participating students, also not permitting teachers to include them in a sequence of activities. This almost exclusive use of the questionnaire to detect students' ideas could lead us to think that it is the only way to find out whether our students (and how many of them) have this or that alternative conception of any socio-ecological conflict.

In order to give up this "edu-myth", the model-based inquiry (MBI [19]) teaching approach allows one to raise phenomena, questions, and controversial activities which serve as triggers for students to express their personal ideas (conceptions, beliefs, myths, etc.) as an initial step; thus, their ideas are put in conflict with the search for evidence and the construction of explanatory models. Likewise, the didactic use of socio-ecological controversies is a current and relevant line of research [20-23] which focuses the science education on giving answers to real problems and promotes the development of systemic thinking and active participation [24,25].

Taking these approaches into account, in this work we want to present the results of the implementation with secondary school students of an MBI instructional sequence, based on a global problem about a real socio-ecological system (SES): the effect of global warming on the Great Barrier Reef [26-28]. This case study looked to extract students' conceptions about coral, the importance of its conservation, and the effects produced by the increase in water temperature on this SES, and, therefore, to address the importance of mitigating the effect of the GW to avoid their loss [29]. For Lehtonen et al. [8], coral reefs offer an example of a complex SES and the need for systems thinking, since the disappearance of the coral caused by the rise in sea water temperature due to the GW $[26-28,30]$ results in large-scale socio-economic challenges, as millions of people base their diets on food from coral reefs [31]. So, it could trigger environmental migration which, in turn, would affect "the structures and stability not only of the countries of origin but also countries where immigration is directed" [8] (p. 347). In addition, the 2030 Agenda for Sustainable Development [32] points to the need to conserve and sustainably use the seas and oceans, as well as the resources they provide and urges for them to be addressed from the educational arena.

\section{Aims of This Study}

In order to face some of these difficulties and be able to address this complex problem in lower secondary school, a model-based inquiry intervention was designed, focused on the search of scientific evidence [33]. The proposal was based on a piece of news about the effect of global warming on the Great Barrier Reef to help students express their ideas about these organisms, to help them rebuild their understanding of why GW affects them negatively, and to sensitize them to the consequences of their disappearance. The results that we show in this article are structured around three objectives: (i) to contribute to raising students' awareness of the problem of GW and its effects on an essential socio-ecological system, such as coral reefs, and to address some of the students' conceptions; (ii) to design a complete MBI sequence which can be reproduced in other contexts; and (iii) to evaluate the effectiveness of the sequence based on the students' perception of what they learned and felt. 


\section{Literature Review}

\subsection{Socio-Ecological Controversies and the Use of News in the Secondary School Classrooms}

The effects of GW on socio-ecological systems represent some of the most prominent recent news, both in written press $[34,35]$ and in environmental education literature [36-38]. This diversity of news (many on social networks [39]) does not automatically make it a direct application resource for the classroom.

It should be noted that scientific divulgation and scientific education may have a common trajectory, but they have well-differentiated objectives [40,41]. So, the use of socio-scientific news requires different strategies [42-44], ranging from the use of the news as a context connected with the curricular content to teach [34,45-47] and critical reading using the CRITIC approach [48], to the use of the news as a trigger for an MBI sequence of tasks, which is the case presented in this work.

The use of news about socio-ecological controversies in the classroom should not be oversimplified, i.e., it is not enough to show them to the students to be understood, be critically analyzed, and have conclusions drawn about them independently [49,50]. The understanding and argumentation process requires a teaching approach of a dialogical, discursive, and social nature, anchored in the phenomena that appear in the news, which can be translated into different teaching approaches (inquiry, modeling, problem-based learning, etc. [43]). This is the case of the PreSEES project [51,52] in which, assuming an argumentation-based approach [53], the socio-ecological controversy arises, the different positions-groups of those affected are analyzed to elaborate a first position, and evidence is used to elaborate increasingly sophisticated arguments until elaborating one with counterarguments and refutations, following a scheme of improvement of Toulmin's argumentation [54].

In the following sections, we justify our teaching approach-model-based inquiry (MBI) approach-based on the need to contradict the students' alternative conceptions by changing the way of generating and validating their knowledge through scientific practices (inquiry and modeling) and to contribute to raising students' awareness of the Great Barrier Reef bleaching problem as an indicator of global warming.

\subsection{Students' Conceptions Related to Global Warming and Coral Reefs}

Numerous studies show the difficulty of the population to define global warming, its causes, and consequences $[5,55,56]$. For Meira [57], it is a very complex problem which shows a set of obstacles related to the difficulty of citizenship, in general, and young people, in particular

- to understand the relationships between the biosphere-atmosphere-hydrosphere-geosphere interface, given the need to develop systemic and dynamic thinking that allows us to overcome a static and fragmented vision of the interactions produced in this interface [58,59];

- to interpret large-scale spatial and temporal changes, since their effects on the environment, economy, and health are transboundary and usually occur at medium or long-term, hardly noticeably, as well as to understand changes on a molecular scale, such as those related to biogeochemical cycles $[57,58,60]$; and

- to recognize the indirect cause-effect relationships between our individual and collective actions, and their consequences for global change [10,57].

The literature review performed by reference [5] about students' conceptions of GW found that high school students were often unclear about the role of humans in this problem, as well as an extended lack of perceived personal responsibility. Furthermore, students do not understand which of their specific daily actions can potentially impact climate change. For Daniel et al. [61], this lack of direct cause-effect link may reduce students' motivation to make the necessary changes to face this problem, which usually are personally and socially costly.

In the case of the Great Barrier Reef, these obstacles become even more apparent. On one hand, students show difficulties recognizing coral as a living being and, specifically, as an animal. In this 
sense, reference [62] reported a generalized trend to consider only animals as living beings, rather than plants, fungi, and bacteria. Nevertheless, students seldom include coral within the animal kingdom, since these organisms do not clearly show some of the characteristics that one would expect-according to the student's conception-in this group: movement [63]. In addition, they are not seen as animals due to their calcareous appearance. In these regards, some authors have reported the difficulties to identify that living beings or parts of living beings which have mineral or rigid appearance are formed by cells [64-66]. Therefore, if they do not identify coral as living beings, they will hardly recognize their vulnerability to GW or the importance of their loss.

The analysis of students' understanding of marine resource management performed by Brody [29], also revealed several misconceptions. Among others, many students believe that coral reefs exist only throughout the Atlantic Ocean, and that the oceans are a balance system with limitless resources. It has been also highlighted the extreme difficulties to understand the effect of GW on coral reefs, since certain scientific contents related to "the $\mathrm{pH}$ scale, acid-based chemical reactions, and the molecular behaviour of $\mathrm{CO}_{2}$ in seawater", which are addressed in subsequent courses according to the Spanish Official Curriculum for secondary education, and which would aid in students' understanding [60] (p. 2). Furthermore, since some students maintain that certain deep aquatic plants do not need light, it will make it more difficult to understand the symbiotic relationships taking place in coral reefs. Even university students did not make reference to the biological diversity existing in coral reefs when they were asked to describe what they saw on a collage of this system [67].

Moreover, some research has investigated students' understanding of the impact of GW on the ocean, whose findings showed that students tend to focus primarily on the direct effects, such as sea level rise, but seldom they recognize the indirect effects of ocean temperature changes $[68,69]$. It seems that high school students do not consider ocean acidification to be an impact of climate change, perhaps due to the difficulties related to the scientific understanding of the effect at a molecular level [60]. Neither did the undergraduates who participated in the study of Lorenzo-Rial et al. [11], since around $85 \%$ of them ignored the effects and consequences on oceans acidification due to anthropogenic $\mathrm{CO}_{2}$ emissions. In addition, reference [70] demonstrated secondary school students' difficulties with the idea that $\mathrm{CO}_{2}$ dissolves in water, as well as with the role of oceans in the carbon cycle. For Howard et al. [71], these conceptions related to chemistry and greenhouse gases may prevent students from correctly conceptualizing the related scientific processes and phenomena, such as the coral reef bleaching due to the rise of the ocean temperature.

Beyond the difficulties to recognize coral as living beings, these misconceptions suggest important obstacles to assess the vulnerability of coral reefs to global warming, and to value the relevance of this SES to maintain biodiversity and the ecosystem services associated with it. Moreover, in the cases they do, students tend to give them a strictly ecological value, a necessary perspective, but insufficient $[10,72]$. Then, their disappearance could be perceived as a completely distant problem from society, or the socio-economic consequences are not considered.

Due to the little research found about misconceptions regarding coral and their role in the ecosystem, we claim that more research is needed to go in-depth in it. In this regard, this work also tries to contribute to this arena.

It should be noted that several authors have highlighted that high school students tend to assume the idea of "balance" in nature when they talk about biodiversity [14]. According to these authors, this trend might be difficult for them to recognize and value species evenness and changes in the face of global environmental drives, such as GW. Even university students show a strong belief in an extremely resilient "balance of nature", since they maintain that it is very likely that disturbed ecosystems can fully recover their initial states [73].

These and other misconceptions, if they are not adequately addressed, might represent a limitation to understand information and news, to feel involved not only in the causes but also in the consequences of the problems, and, as aforementioned, to encourage the necessary personal and collective changes to face global warming. 


\subsection{Scientific Practices for Knowledge Building}

Science education research has shown that progress from alternative explanations to scientific ones requires bringing students closer to the ways of thinking, doing, accepting, and communicating knowledge which are proper to science, reflected in a set of scientific practices that can be grouped into practices of inquiry, modeling, and argumentation [53]. In this article, we focus on the former two.

On one hand, inquiry is the process of searching for evidence to contrast explanations. Teaching tasks related to inquiry may include a question or any trigger that leads to express and discuss explanations, dealing with a phenomenon, selecting or designing the process of searching for evidence to contrast the statements, and analyzing and communicating results [33]. A deformed version of this practice is its reduction to mechanical laboratory activities, a practice which does not reflect actual scientific activity and does not allow the generation and validation of knowledge [54].

On the other hand, modeling is the process of building, using, and evaluating models [74,75]. A model is a simplified representation of a system, which selects its most relevant issues in order to describe, explain, and predict phenomena. Alternative explanations may be considered initial models, although unstable, unrelated, and referring to particular phenomena, while scientific explanations can be considered models of greater complexity and generality. Teaching tasks related to modeling may be building a model to explain a data set, using a model to make and justify hypotheses, or assessing a model according to a set of results or for its conceptual consistency. A deformed version of this practice is its reduction to the learning of already elaborated models.

Learning to participate in scientific practices requires carrying out specific activities in the classroom and organizing teaching as sequences of tasks or activities structured around them [54,74,75]. Several international reports and projects have recommended that the inquiry process becomes the backbone of teaching, under the common name of inquiry-based science education (IBSE). Numerous quantitative studies have shown the effectiveness limited of non-guidance IBSE and the benefits of guidance IBSE in learning scientific skills [76-81]. Furthermore, IBSE engages students in learning [82,83], enhancing their attitudes, motivation, interest, self-confidence, and expectations for the future [33]. A necessary benefit of using IBSE as a teaching approach is it promotes the commitment of girls to science and scientific professions [76-79].

Regarding conceptual learning, IBSE is shown to be effective when it is developed in a structured way, breaking down the process of inquiry into tasks, guided by the teacher $[84,85]$.

Frequently, IBSE is reduced to manipulative activities, reproducing an empiricist image of science and achieving a particular explanation for a specific phenomenon, but it lacks the inclusion of modeling and general explanations [81]. In order to face this deformation, the model-based inquiry approach (MBI) aims at effectively integrating the different scientific practices, placing the model that is intended to be built or assessed at the heart of the process.

According to reference [54], the following types of tasks could be the reference-not algorithmic sequence-for an MBI teaching approach.

- Establish a discussion context in which the question to be investigated makes sense for students and promotes their own ideas (hypotheses).

- Express and discuss hypotheses, sometimes justified in an alternative model and other times, a scientific one.

- Express and discuss potential evidence-seeking designs about these hypotheses. This design may be for direct information, observation, or experimentation.

- Obtain the data, communicating, and interpreting them to transform them into evidence, drawing conclusions about the validity of the hypotheses.

- Argue the validity of new models according to the evidence obtained. Apply those ideas to new situations and evaluate them.

The emphasis, the selection, or combination of these types of tasks would lead to different MBI cycles. In any case, until reaching a teaching sequence, it is necessary to previously identify which 
model or key ideas of the model we want students to learn, what context and which question will make sense of the topic, which design will be the most appropriate, which data and information will be analyzed, and which conclusion is expected to be reached.

The next step will be to specify the statement of each task to be presented to the students and to foresee the difficulties that will be found. This is described in detail below, for the development of our sequence based on the analysis of the effect of GW on the Great Barrier Reef.

\section{Materials and Methods}

In order to potentially implement, adapt, or reproduce the results, full details of the MBI sequence of tasks are provided in this section.

\subsection{Participants}

This sequence of tasks was put into practice with two groups of students, belonging to the first year of secondary school in the province of Almería (SE Spain), with 25 and 22 participants respectively (13-14 years old). All the tasks were written individually by each student in their notebook and presented in small groups of four and, after this initial debate, in a large group. In this way, we ensured the widest possible diversity of ideas expressed by students and the search for consensus.

\subsection{Description of the Model-Based Inquiry (MBI) Approach Instructional Sequence and Data Collection}

The difficulties of recognizing as living what has a calcareous appearance and the barrier that this can pose to identify these socio-ecological systems as indicators of global warming, described in Section 3.2, led us to consider the need that, during the MBI sequence, students should build the following key ideas.

- Coral are living beings and constitute the habitat of other marine organisms.

- Coral reefs are important and global warming affects them.

- $\mathrm{GW}$ needs to stop to minimize the impacts on this socio-ecological system.

The designed proposal consisted of 16 tasks, structured in three blocks, as described below, which were implemented in an exceptional session, which took $3 \mathrm{~h}$ of intensive work.

1. A first block of questions, prior to reading the news, aimed at introducing students to the subject and engaging them through the expression of their personal ideas about whether coral are living beings or not. Therefore, this Block 1 of tasks (Table 1) was intended for students to express their personal ideas about coral and to put them into conflict.



Figure 1. Images that accompany Block 1, from left to right and from top to bottom: coral, mussels, stones, and a seahorse. Retrieved from www.hdfondos.eu/, www.zonadigitalonline.com/, https: //www.dicoro.com/, http://www.abih-pe.com.br/, respectively. 
Table 1. Block 1 of tasks: Expression of personal ideas.

\begin{tabular}{|c|c|}
\hline Tasks & $\begin{array}{l}\text { Model-Based Inquiry } \\
\text { (MBI) Stage }\end{array}$ \\
\hline $\begin{array}{l}\text { T1. Name the following images and determine if each of them shows a living or non-living being (Figure } 1 \text { ). } \\
\text { T2. In the previous images, point out where there are plants and why you know they are plants. (In case they } \\
\text { answer that with "photosynthesis", teacher asks, "How do you know they do photosynthesis?"). } \\
\text { T3. Many of you have chosen that the mussel is a living being and others say no, how would you convince } \\
\text { your colleagues that they are wrong? } \\
\text { T4. Does photo } 1 \text { (top left of Figure 1) show a living being? How do you know? What criteria do you have to } \\
\text { justify it? }\end{array}$ & $\begin{array}{c}\text { Expression of personal } \\
\text { ideas. Express/use initial } \\
\text { models }\end{array}$ \\
\hline
\end{tabular}

2. A second block of tasks (Table 2) addressed a scientific news article, entitled "The Great Barrier Reef is threatened by global warming". This news represents the context and the question that will give meaning to the inquiry. In the classroom, following the Jigsaw method, the news was divided into four parts- the number of students per working group [86]. Each student did an individual reading of their part and wrote down the most important ideas, which they shared with the rest of their classmates from the different groups who read the same part, in order to have a more complete vision. Finally, they returned to their starting group to share the summary of the main ideas of each part of the news.

Table 2. Block 2 of tasks: Contextualization and appropriation of the object of inquiry by means of the news.

\begin{tabular}{cc}
\hline Tasks & MBI Stage of the Inquiry \\
\hline T5. Read the news and explain what it is about. & Contextualization and \\
T6. Why do you think we are going to work on this news in the biology and geology subject? & appropriation of the object of MBI. \\
\hline $\begin{array}{c}\text { T7. Write everything you know about coral. } \\
\text { T8. Read the news The Great Barrier Reef is threatened by global warming } \\
\text { (Retrieved from https://mx.blastingnews.com/) }\end{array}$ & Recognize the need for a model \\
\hline
\end{tabular}

3. A third block of tasks is shown in Table 3; the news was used as the context of the MBI approach, giving meaning to all the previous tasks. Particularly, students were asked to use graphic language to show what they thought about coral (task T9); in addition, they were asked to look for an explanation about how they believe that the increase in temperature affects coral so that they are disappearing, as the news suggests. The following task (T10) was intended for the students to recognize the symbiotic relationship with algae and the effects of increasing water temperature on this relationship. Likewise, within the tasks T11-T13, students were asked for arguments to justify their ideas to build the coral model as a living being. In order to justify coral reproduction (T12), the vital function less known to them, a video was provided [87] in which they could observe the spawning of the coral. These tasks, aimed at searching for evidence that supports coral are living beings, become especially relevant in the sequence to understand the symbiotic relationship with algae, and their vulnerability to GW. Based on all the evidence which they gathered throughout the sequence (they reproduce, they feed, they breathe, and they relate), students may conclude that coral are living beings (T14). Now, we needed to create a model that explains why coral die when the water temperature increases due to the GW effect (T15). At this point, with the evidence gathered in the reading of the news and searching on the Internet, we considered that the students may be able to build the conclusion about the effects of the increase in sea temperature: the algae, which live with the coral, disappear; therefore, the coral remain without sufficient nutrients, whitening; and, if the effect persists, coral may end up dying.

As a final task (T17), in order to make students aware of the effect of what they have learned and felt during the MBI instructional sequence, we conducted a questionnaire based on a Knowledge and Prior Study Inventory (KPSI) approach to self-regulate learning (Table A1, in the Appendix A). This tool considers the participants' knowledge before and after experiencing the sequence, through Likert scale responses, as well as the emotions felt during the sequence $[33,88]$. 
Table 3. Block 3 of tasks: Searching for evidence and building the explicative model.

\begin{tabular}{|c|c|c|c|}
\hline \multicolumn{3}{|c|}{ Tasks } & MBI Stage \\
\hline \multicolumn{4}{|c|}{$\begin{array}{l}\text { T9. The news indicates that the coral is disappearing due to the increase in sea water temperature. } \\
\text { Draw how you imagine a coral looks and how you think the increase in temperature affects it. } \\
\text { (Table proposed to students in task T9 of the sequence): }\end{array}$} \\
\hline Draw a coral & $\begin{array}{c}\text { Draw Coral When } \\
\text { Temperature Increases } \\
\text { One Degree }\end{array}$ & $\begin{array}{l}\text { Draw Coral a Few } \\
\text { Months after the Increase } \\
\text { in Temperature }\end{array}$ & $\begin{array}{l}\text { Search for answers based on previous ideas } \\
\text { and justification } \\
\text { Express/use initial model }\end{array}$ \\
\hline $\begin{array}{c}\begin{array}{c}\text { Indicate what are coral are } \\
\text { made of }\end{array} \\
\end{array}$ & \multicolumn{2}{|c|}{ Indicate what changes and what remains } & \\
\hline \multicolumn{3}{|c|}{$\begin{array}{l}\text { T10. The news says: "Global warming is a great threat to the coral due to the increase in water } \\
\text { temperature and it expels the algae that grow inside them. This destroys their main source of } \\
\text { energy", that is, their food. Does it coincide with what you have drawn before? What does this } \\
\text { information about coral give you? } \\
\text { T11. How do coral feed? Do they perform other vital functions? What evidence do we have? } \\
\text { T12. Do coral reproduce? How? What evidence do we have? } \\
\text { T13. Do they breathe? What evidence do we have? } \\
\text { T14. We already have proof that coral are living things. But do you think they are animals or plants? } \\
\text { What evidence do we use to find it out? }\end{array}$} & $\begin{array}{l}\text { Search for evidence } \\
\text { Test the initial model }\end{array}$ \\
\hline \multicolumn{3}{|c|}{$\begin{array}{l}\text { T15. It seems that we are ready to understand the news, so what do you think could be happening } \\
\text { to coral when the sea water increases a degree? }\end{array}$} & $\begin{array}{l}\text { Come to and communicate conclusions } \\
\text { Express final model }\end{array}$ \\
\hline \multicolumn{3}{|c|}{$\begin{array}{l}\text { T16. Once you know what is happening to coral reefs, answer these two questions: Why is } \\
\text { conserving coral reefs important? What can we do to reduce coral bleaching? }\end{array}$} & Transfer to other contexts-news \\
\hline
\end{tabular}

\subsection{Data Analysis}

A descriptive analysis and inferential statistics were applied to determine the frequency of the students' responses. In the application of inferential statistics, dependent samples were considered, so Student's $t$-test and Correlation analysis were used, with a significance level of $\alpha=05$.

Taking into account the characteristics of the study, the validity of the questionnaire focused on the validity of the content through the judgment of experts referring to the selection of key items and emotions: its relevance to the aims of the study and its suitability for the sample. This task was carried out by the Sensociencia Project's research team.

The reliability of the results referring to the self-regulation of learning, being ordinal variables, was studied using the Cronbach coefficient. The reliability of the results referring to the self-regulation of learning was studied using the Cronbach coefficient. The value of the coefficient was 0.918 , a very acceptable value according to reference [89].

The reliability of the results referring to emotions, being dichotomous variables, was studied using the Kuder-Richardson coefficient. The negative value of the coefficient referring to the experienced emotions construct indicated that the whole questionnaire was not reliable because the sample is reduced. To further refine the study of reliability in relation to emotions, the questionnaire was decomposed into nine sub-questionnaires, taking as a construct in each of them the experience of a particular emotion through different key moments or items in the sequence. In this case, the following values of the Kuder-Richardson coefficient showed moderate or high reliability on concentration: 0.839; interest: 0.835 ; confidence: 0.544 ; satisfaction: 0.694 ; insecurity: 0.376 ; and dissatisfaction: 0.442 .

\section{Results}

Below, we show the main results of the sequence of tasks, structured according to the three indicated aims.

\subsection{Students' Conceptions}

Almost all students (>90\%) thought that both mussels and coral are living beings (T1), although the remaining answers confirmed the existence of alternative conceptions related to the fact that the rigid or calcareous is not alive due to its resemblance to inert matter [64-66]. In addition, by naming the latter, some students indicated that they are plants, algae, or the seabed. In fact, when students were asked about the existence of plants in the images shown in Figure 1 (T2), all of them indicated that 
coral were plants, except one student who defended from the beginning that coral belong to the animal kingdom. For T4, criteria were also requested to justify whether coral are living beings. The most common answer referred to the fact that coral are living beings because they perform the three vital functions (Table 4). This is important because this is the model that is expected that students reach through this sequence, looking for evidence that confirms it.

Table 4. Justifications provided by the students to answer task T4. Responses are displayed in decreasing order of appearance.

Coral Are Living Beings Because ...
They perform the 3 vital functions $(43.75 \%)$
Fish inhabit in them and feed on them $(12.5 \%)$
It is marine vegetation $(12.5 \%)$
They carry out photosynthesis $(10.42 \%)$
They breathe because they release bubbles $(6.25 \%)$
Algae and coral are plants that make their own food $(4.17 \%)$
Because they cannot live without light $(4.17 \%)$
Because it appears in the biology book $(2.08 \%)$
They are colorful and they are inside the sea $(2.08 \%)$
They feed on plankton $(2.08 \%)$

As a result of the large group dialog about the responses to these tasks, interesting discussions emerged. The student who defended that coral are animals said that in a TV documentary he had watched that they could feed on plankton, facing their classmates who defended that, as they are plants, they create their own food.

Another discussion was generated when students were asked how they knew that coral perform photosynthesis. All their answers were initially related to the green color; but, when a photograph of coral of different colors was shown (Figure 1), their justifications were two. On the one hand, some groups said that only the greens were plants and the rest were rocks. On the other hand, some groups thought that coral without green colors contain other pigments to carry out photosynthesis.

A third debate was generated at this point about reproduction, since there was a group that said that coral do not have seeds, so they cannot be plants; different from the rest of the groups who justified that coral are "some special plants which are reproduced by fragmentation".

Therefore, the set of tasks prior to reading the news met the aims of expressing students' ideas as well as bringing students closer to the content we wanted to discuss.

\subsection{Outputs of the MBI Approach Regarding the Effects of Global Warming on Coral Reefs}

When students were asked to draw the effect of the temperature rise on coral reefs after reading the news (T9), a total of five types of responses provided by students were found. The most frequent argument was that coral, by increasing the temperature of the water by one degree, decrease in size and blanch (Figure 2).

Other responses that appeared quite frequently mentioned that the coral are uninhabited, as can be read in the news, or that the coral are losing pieces. Notably, two students showed that the increase in temperature does not adversely affect the coral and that it continues to grow. Finally, the group which included the student who said at the beginning that coral are living beings showed an interpretation of the entire news at this point (Figure 3), having arrived at the construction of the model.

The following tasks were aimed at gathering different evidence which justifies that coral are living beings, besides helping students with solving task T14. At this point, no group showed problems to justify that coral belong to the animal kingdom.

Task T15 asked students to provide an explanatory model of the effect of the increase in water temperature on coral, caused by GW. Although most of the students (36 students, $76.6 \%$ ) reached the conclusion without problems, as exemplified in Figure 4, there was one group (4 students, $8.5 \%$ ) 
who presented certain difficulties in recognizing the symbiotic relationship between coral and algae; since they provided an incomplete explanatory model, referring, in a very general way, to the fact that coral could not perform their vital functions when ocean temperature increases.

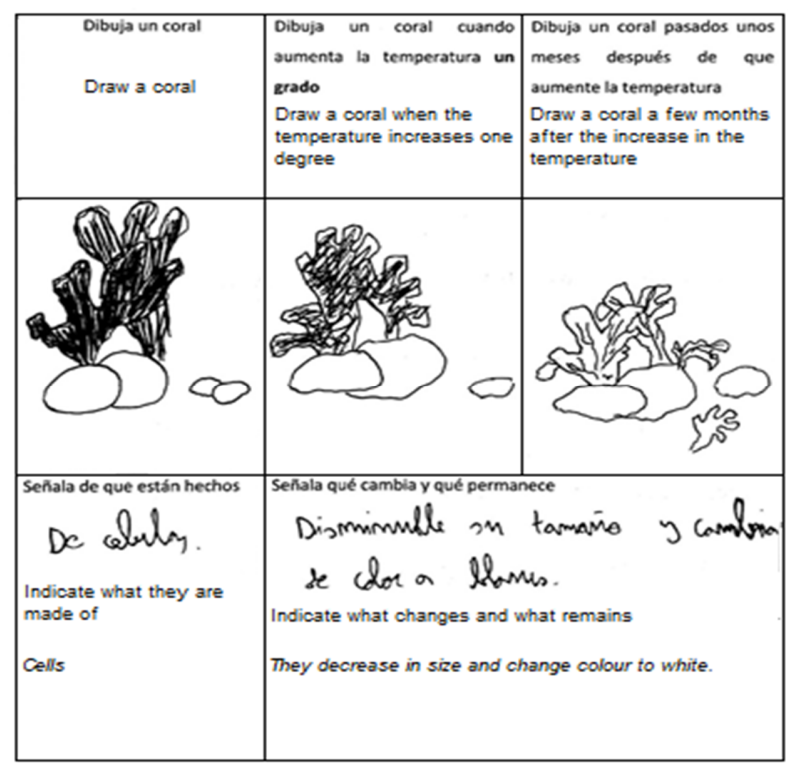

Figure 2. Example of majority responses to task T9.

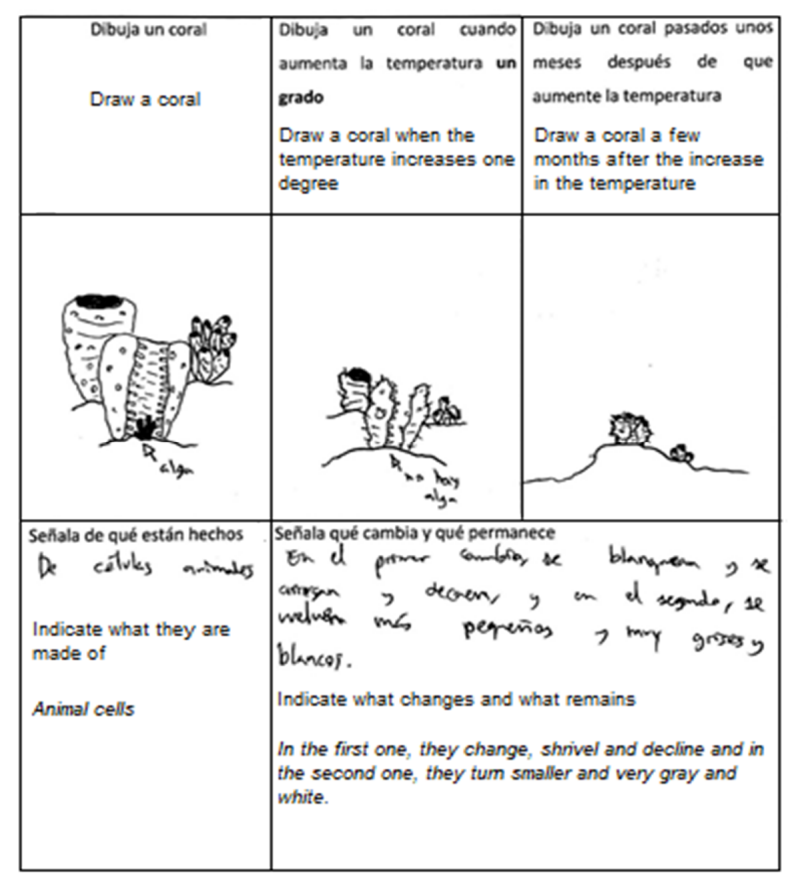

Figure 3. Example of one student's response to task T9.

Eventually, even before questions included in T16 emerged, in the discussion performed in a large group, the need to stop this loss of coral reefs spontaneously arose, due to the involved effects for the rest of the marine communities which inhabit them, as well as the effects on economic activities such as fishing and even tourism. The vast majority of students called for governmental interventions and rules to reduce these threats on coral reefs beyond more individual actions related to reduce our greenhouse gas emissions. 


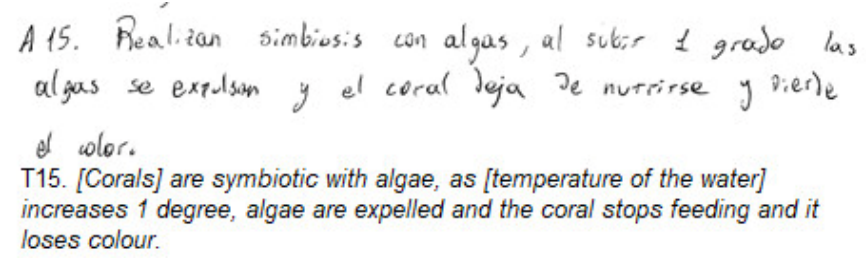

Figure 4. Example of response to task T15.

\subsection{The Effectiveness of the Sequence Based on the Students' Perception of What They Learned and Felt}

Regarding the students' perceptions about what they learned and felt during the implementation of the sequence, they showed an understanding of it, including the news, as well as active participation, implication, and motivation. Furthermore, after putting the sequence into practice, the students were asked to fill out a KPSI questionnaire $[33,88]$ in which they showed the degree of knowledge they believed they had in each of the aspects or key items of the sequence, before and after it, on a scale of 1 to 5 (Table 5), as well as the emotions felt during the process. According to their responses, students perceived that they learned since the degree of knowledge they consider to have after developing the sequence was greater in all questions (Table 5). Although a high degree of knowledge that students considered to have before carrying out the sequence is highlighted, this may reflect that this sequence is contextualized, since it is not a foreign content for them. Particularly, the two items which show the least difference (it means, those for which students recognize lesser learning, since they already knew it before the sequence) were those referred to the self-perception that coral are living beings (M6) and that coral perform vital functions, like all living things (M9).

On the contrary, the highest difference-or the greatest recognition of what the sequence has taught to them-occurred when they addressed the fact that coral are animals (M7), followed by the perceived knowledge about the effect of temperature in coral bleaching (M10) and the prediction of the internal composition of a coral (from what's inside, M4). Another item with a high recognition between what they knew before and after the sequence was related to the prediction of the effect on coral of the increase in water temperature (M5), which highlights the importance of addressing the bleaching of coral reefs as an indicator of global warming.

As shown in Table 5, there were statistically significant differences between what students perceived they knew before and after the implementation of the sequence in all the analyzed key items. Moreover, there were significant correlations between their responses before and after in all key items, except M7 and M10. The correlation coefficients provide a valuable interpretation of these key items where higher increases were perceived (M7 and M10, 0.17 and 0.26 respectively). Likewise, despite the differences in the mean values for M5 and M8 (0.72 and 0.67 respectively), their high correlation coefficients may indicate that previous high scores lead to high after scores (and low before scores with low after ones).

Regarding the emotions felt, students selected mostly emotions such as concentration and interest, which were marked in every item by $100 \%$ of students, followed by satisfaction (55\%) and confidence $(45.5 \%)$, as shown in Figure 5. Moreover, in order to know the results related to each emotion in detail, we identified how many students reported each of them in the eleven key items. These results are shown in Figure 6, appearing in greenish tones for the positive emotions, such as concentration, interest, confidence, and satisfaction, as opposed to the negative emotions, represented by reddish-orange tones.

Figure 6 shows that the items with the most positive emotions (greenish colors) coincide with minds-on items (M1, M7, and M9). This fact, added to that M6 and M7 are the items of the sequence which less negative emotions received, makes us think that it generated confidence, interest, and concentration to know that they identified coral as living beings (M6), for their vital functions (M9) and to learn (greater jump in Table 5) that they were animals and not plants as they initially thought. In addition, it should be noted that M10 (when students address that the increase in sea water temperature kill the coral, since the symbiotic algae leave) was the item that aroused more interest. 
On the other hand, insecurity was scarce albeit continuous along the sequence, except in M6 and M9, while M4 and M5 received higher scores of negative emotions. These might point that both predictions (of the internal composition of coral and the effects of the increase in sea water temperature on coral) were the items where students felt worse, which coincides with their low self-perception of what they knew after the sequence (Table 5).

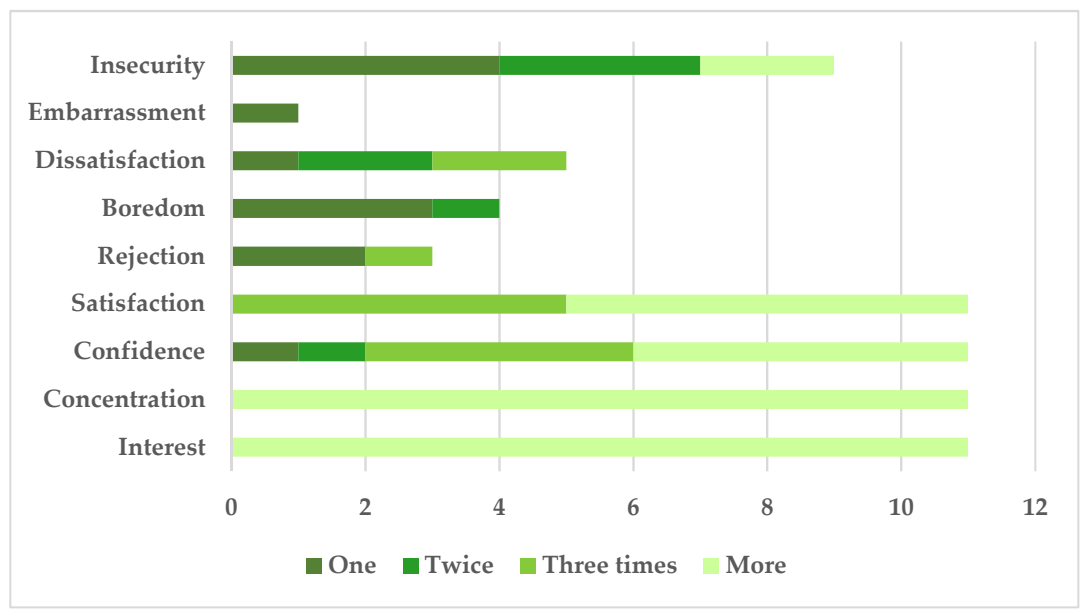

Figure 5. Frequency of students who have experienced each emotion along the sequence.

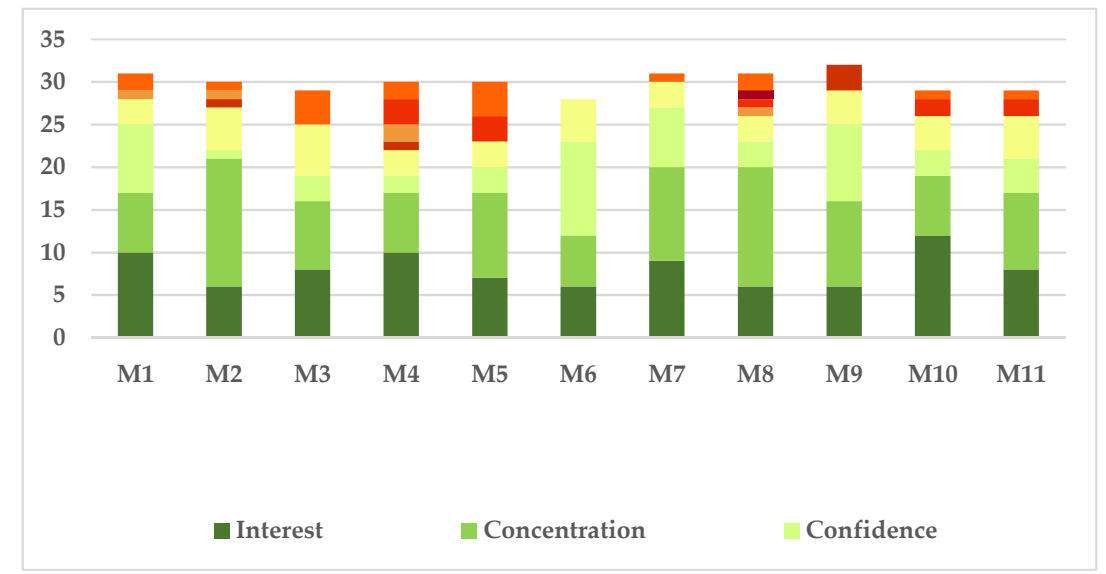

Figure 6. Frequencies of emotions felt by students for each item of the sequence.

Table 5. Students' perception of what they have learned (where 'Sig' means the significance level and ${ }^{\prime *}$ when this level is $\left.<0.05\right)$.

\begin{tabular}{cccccccccc}
\hline \multirow{2}{*}{ Key Items $^{1}$} & \multicolumn{2}{c}{ BEFORE } & \multicolumn{2}{c}{ AFTER } & DIF. & \multicolumn{2}{c}{ Bilateral Significance } & \multicolumn{2}{c}{$\begin{array}{c}\text { Correlation } \\
\text { Before-After }\end{array}$} \\
\cline { 2 - 10 } & Mean & SD & Mean & SD & & T & Y/N & Coeff & T (Sig *) \\
\hline M1 & 3.66 & 1.01 & 4.62 & 0.56 & 0.96 & 0.000 & Yes & 0.79 & $0.000^{*}$ \\
M2 & 2.62 & 1.27 & 3.86 & 0.88 & 1.24 & 0.000 & Yes & 0.77 & $0.000^{*}$ \\
M3 & 3.03 & 1.15 & 4.03 & 0.91 & 1 & 0.000 & Yes & 0.80 & $0.000^{*}$ \\
M4 & 1.86 & 1.13 & 3.52 & 1.15 & 1.66 & 0.000 & Yes & 0.41 & $0.026^{*}$ \\
M5 & 2.41 & 1.18 & 4.00 & 0.96 & 1.59 & 0.000 & Yes & 0.72 & $0.000^{*}$ \\
M6 & 3.97 & 1.27 & 4.76 & 0.44 & 0.79 & 0.000 & Yes & 0.58 & $0.001^{*}$ \\
M7 & 2.55 & 1.45 & 4.72 & 0.53 & 2.17 & 0.000 & Yes & 0.17 & 0.38 \\
M8 & 2.59 & 1.05 & 4.10 & 0.94 & 1.51 & 0.000 & Yes & 0.67 & $0.000^{*}$ \\
M9 & 4.00 & 1.28 & 4.59 & 0.87 & 0.59 & 0.001 & Yes & 0.70 & $0.000^{*}$ \\
M10 & 2.21 & 1.15 & 4.21 & 0.90 & 2 & 0.000 & Yes & 0.26 & 0.174 \\
M11 & 3.55 & 1.24 & 4.45 & 0.87 & 0.9 & 0.000 & Yes & 0.62 & $0.000^{*}$ \\
\hline
\end{tabular}

1 where, M1: Differentiation between living and non-living matter; M2: Scientific news understanding; M3: Relate the subject of biology with scientific news; M4: Predict the internal composition of coral; M5: Predict the effects of temperature rise; M6: Coral are living beings; M7: Coral are animals; M8: Search for evidence to prove that coral are animals; M9: Living beings perform the three vital functions; M10: Temperature rise kills coral; M11: We must stop global warming. 
Items related to scientific news (M2 - read the news and M8-search for evidence) were the items where students acknowledged having had greater concentration. The highest value of satisfaction was being able to relate the subject of biology with scientific news (M3) followed by M11 (we must stop global warming).

\section{Discussion and Educative Implications}

Global warming is a significant issue for students as future voters and decision makers [71]. Thence, we claim the need to design appropriate learning experiences, in which pre-existing conceptions play a crucial role in active knowledge construction. It has been considered "essential that climate education be based on a scientific understanding of socio-ecological systems", such as coral reefs [8] (p. 366) which are recognized as an appropriate example of complex SESs, and which agglutinate numerous alternative conceptions, as shown in Section 3.2.

In this vein, reference [5] highlighted the importance of certain characteristics of educational instruction, such as addressing alternative conceptions and engaging students in scientific discourse, to facilitate their understanding of complex, controversial, and multifaceted socio-scientific issues such as global warming. Thus, the didactic use of these kind of controversies in the classrooms, as well as the use of related news, might promote, not only the use of scientific knowledge to give answers to real problems, but also the development of critical thinking and active participation by students [22,25]. Likewise, instruction based on these kind of controversies has been recognized as an effective way for students to contextualize the learning of science within complex social and ecological issues [12].

To do this, an MBI teaching approach was shown to be a very appropriate way for "students to leverage their existing knowledge and their investigative skills to find and internalize new knowledge and solutions" to formulated questions, and for applying these learnings to an increasingly complex world [90] (p. 20). In this sense, an MBI approach tries to involve students in scientifically oriented questions and formulate explanations based on argumentation and evidence collection [19].

Taking all this into account, we decided to address a socio-ecological controversy in a classroom, following the model-based inquiry approach [14,36]. Thus, starting from a news article about the effects of GW on a real socio-ecological system, the Great Barrier Reef, the proposal looked to contradict certain students' alternative conceptions and to make them progress in the construction of the required content for the understanding of the bleaching of the reef, as an indicator of GW. Thus, we aimed to contribute to raising students' awareness of this problem.

For this purpose, a specific MBI instructional sequence consisting of 17 tasks was designed, based on the alternative conceptions of students described in the literature review and focused on the search for scientific evidence [14].

Results showed that the implementation of the sequence allowed students to mobilize their conceptions about coral reefs and symbiotic relationships. In particular, although some of the participants maintained that the rigid or calcareous parts are not alive due to their resemblance to inert matter criteria, students finally recognized that coral are living beings, basing their answers on the fact that coral perform the three vital functions. The search for criteria to classify coral as living beings promoted a key aspect in the process of constructing scientific knowledge: the consideration of evidence [91].

Likewise, the implementation of the sequence seemed to favor the development of scientific knowledge about the consequences of GW on the reefs. As shown in Section 5, students frequently argued that coral decrease in size and blanch when sea water temperature rises. Even one of the working groups was able to show a detailed interpretation of the phenomenon of reef bleaching, reaching the construction of the model. On the other hand, there were two students who did not progress as expected, since they maintained certain difficulties in recognizing the symbiotic relationship between coral and algae and they affirmed that the increase in temperature did not adversely affect the coral. Therefore, they still provided an incomplete explanatory model.

Moreover, the sequence could be considered effective, according to the students' self-perception about what they have learned and felt, analyzed by means of a KPSI questionnaire. Among the most 
experienced emotions, students showed concentration and interest (both selected by $100 \%$ of students), followed by satisfaction and confidence (Figure 5), whereas insecurity, boredom, dissatisfaction, and rejection were experienced less.

Although undervalued in many works that assess the effectiveness of educational interventions, numerous authors in science education have highlighted the importance of emotions in learning [33,88,92]. According to reference [93] (p. 241), there is evidence "that positive emotions and enjoyment from learning science play a significant role in the learning outcomes and serve as a driving force for self-learning, and retaining knowledge".

On the other hand, numerous research papers have pointed out the existing gap between research and practice [94], since results from research are not transferred to actual teaching practice. In this regard, authors of [95] have pointed out some obstacles, such as those related to its scarce generalization (particular contexts of application) or the lack of sharing design or common theoretical frameworks. In order to-modestly - contribute to reducing this gap, in this work we shared the entire information used for the design and implementation of the sequence, in order to facilitate its reproduction in other contexts.

One of the weaknesses of our instructional sequence about coral reefs was related to the design for searching for evidence, which should have been provided by the students; nevertheless, for reasons related to the lack of time during implementation, in this case, it was designed by the teacher. Future works should address this weakness, assigning the students to design the procedures for the search for evidence.

In this work, students were able to explain the effects of the GW on coral reefs, even mentioning the negative impacts on other marine organisms related to the reefs, as well as socio-economic effects of their loss on fisheries and tourism. Nonetheless, according to numerous authors, this improvement on their knowledge of natural phenomena and humans' impact on the environment is not enough to increase their individual responsibility and to act sustainably $[96,97]$. In this regard, our results are in line with those reported by references $[10,98]$, in which, despite the progression of the knowledge that students showed about the causes and consequences of different socio-ecological problems, there still exist important barriers to achieve the generation of commitments and changes towards individual pro-environmental behaviors; in other words, it does not directly mean that this progression could be translated into real individual actions. Reference [10] also concluded that students show some difficulties to recognize the social and economic dimensions of socio-ecological problems. Therefore, future uses of the sequence described here should emphasize the socio-economic importance of coral reefs, as well as the impacts of our individual and local actions on global and, sometimes, distant socio-ecological systems, since intentions of taking pro-environmental action may be activated "when students believe that things they value are in danger" [99] (p. 4).

Finally, we encourage readers to replicate or improve this proposal because, with this, we will help reduce the gap between didactic research and teaching practice.

Author Contributions: M.R.J.-L. and M.G.-H. had the original idea, implemented the sequence, collected the data, and contributed to the writing of the paper. I.B.-G. wrote and edited the paper and prepared the discussion. All authors have read and agreed to the published version of the manuscript.

Funding: This paper is partially funded by MINECO (with FEDER funds, EDU2017-82197-P), and Ministerio de Ciencia, Innovación y Universidades (PRX19/00364) of the Government of Spain.

Conflicts of Interest: The authors declare no conflict of interest, and the funders had no role in the design of the study; in the collection, analyses, or interpretation of data; in the writing of the manuscript; or in the decision to publish the results. 


\section{Appendix A}

Knowledge and Prior Study Inventory (KPSI) approach to self-regulate learning.

Table A1. Task 17. Value on a scale of 1 to 5 what you have learned about each of the following items, where 1: I know nothing, 2: I know a little, 3: I know it, 4: I know it very well, 5: I know it and I could explain it to my classmates.

\begin{tabular}{|c|c|c|c|}
\hline $\begin{array}{l}\text { Before the Sequence } \\
\qquad(1,2,3,4,5)\end{array}$ & Knowledge About... & $\begin{array}{l}\text { After the Sequence } \\
\quad(1,2,3,4,5)\end{array}$ & $\begin{array}{l}\text { Emotions Felt in Each of the Following Aspects } \\
\text { Indicate How You Felt While You were Carrying Out Each } \\
\text { Process and the Reason Why You Have Felt It or Them }\end{array}$ \\
\hline & $\begin{array}{l}\text { Differentiation between living } \\
\text { and non-living matter }\end{array}$ & & 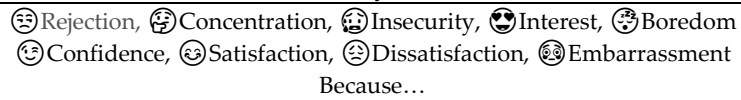 \\
\hline & Scientific news understanding & & 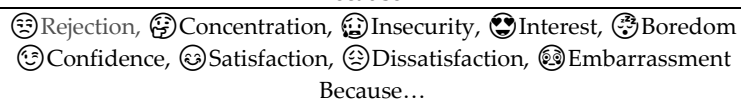 \\
\hline & $\begin{array}{l}\text { Relate the subject of biology } \\
\text { with scientific news }\end{array}$ & & 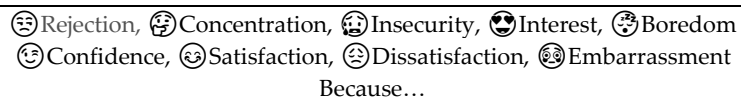 \\
\hline & Predict the internal composition of coral & & 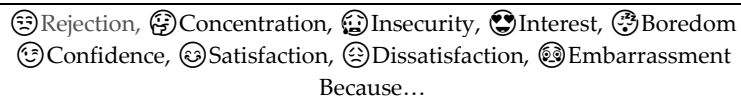 \\
\hline & Predict the effects of temperature rise & & 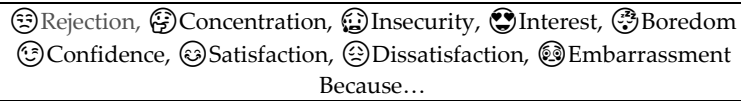 \\
\hline & Coral are living beings & & 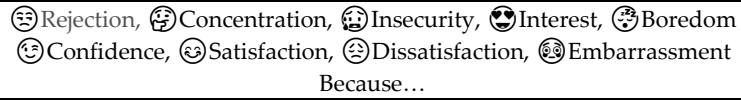 \\
\hline & Coral are animals & & 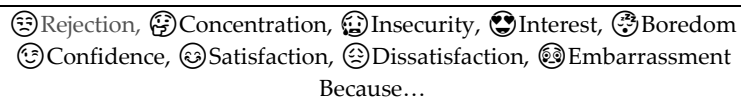 \\
\hline & $\begin{array}{l}\text { Search for evidence to prove } \\
\text { that coral are animals }\end{array}$ & & 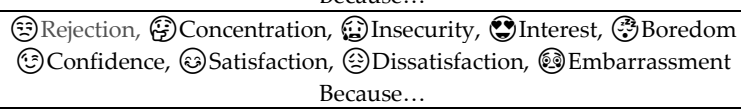 \\
\hline & $\begin{array}{l}\text { Living beings perform } \\
\text { the three vital functions }\end{array}$ & & 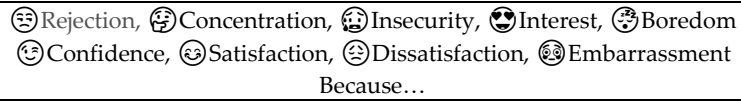 \\
\hline & Temperature rise kills coral & & 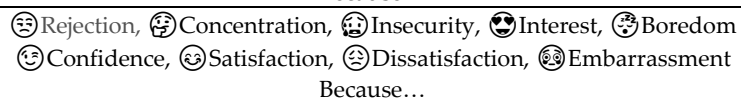 \\
\hline & We must stop global warming & & 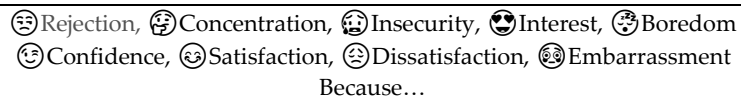 \\
\hline
\end{tabular}




\section{References}

1. UN. United Nations Framework Convention on Climate Change. Available online: https://unfccc.int/ resource/docs/convkp/conveng.pdf (accessed on 30 April 2020).

2. Cook, J.; Oreskes, N.; Doran, P.T.; Anderegg, L.; Verheggen, B.; Maibach, E.; Carlton, J.S.; Lewandowsky, S.; Skuce, A.G.; Green, S.; et al. Consensus on consensus: A synthesis of consensus estimates on human-caused global warming. Environ. Res. Lett. 2016, 11, 048002. [CrossRef]

3. Fisher, D.R. The broader importance of \#FridaysForFuture. Nat. Clim. Chang. 2019, 9, 430-431. [CrossRef]

4. Yeh, S.C.; Huang, J.Y.; Yu, H.C. Analysis of energy literacy and misconceptions of junior high students in Taiwan. Sustainability 2017, 9, 423. [CrossRef]

5. McNeill, K.L.; Vaughn, M.H. Urban high school students' critical science agency: Conceptual understandings and environmental actions around climate change. Res. Sci. Educ. 2012, 42, 373-399. [CrossRef]

6. Reis, P. Promoting students' collective socio-scientific activism: Teachers' perspectives. In Activist Science and Technology Education; Bencze, J., Alsop, S., Eds.; Springer: Dordrecht, The Netherlands, 2014; Volume 9, pp. 547-574. [CrossRef]

7. Varela-Losada, M.; Arias-Correa, A.; Vega-Marcote, P. Training Teachers Committed to Climate Change Mitigation. In Climate Literacy and Innovations in Climate Change Education; Azeiteiro, U.M., Leal Filho, W., Aires, L., Eds.; Springer: Cham, Switzerland, 2018; pp. 307-321. [CrossRef]

8. Lehtonen, A.; Salonen, A.O.; Cantell, H. Climate Change Education: A New Approach for a World of Wicked Problems. In Sustainability, Human Well-Being, and the Future of Education; Palgrave Macmillan: Cham, Switzerland, 2019; pp. 339-374. [CrossRef]

9. Banos-González, I.; Martínez-Fernández, J.; Esteve, M.A. Using dynamic sustainability indicators to assess environmental policy measures in Biosphere Reserves. Ecol. Indic. 2016, 67, 565-576. [CrossRef]

10. Esteve-Guirao, P.; Jaén, M.; Banos-González, I. The Interdependences between Sustainability and Their Lifestyle That Pre-Service Teachers Establish When Addressing Socio-Ecological Problems. Sustainability 2019, 11, 5748. [CrossRef]

11. Lorenzo-Rial, M.A.; Álvarez Lires, M.M.; Arias Correa, A.; Pérez Rodríguez, U. Learning how to interpret ocean acidification with on-line resources in a contextualised experimentation scenario. Ensen. Cienc. 2019, 37, 189-209. [CrossRef]

12. Hancock, T.S.; Friedrichsen, P.J.; Kinslow, A.T.; Sadler, T.D. Selecting Socio-scientific Issues for Teaching. Sci. Educ. 2019, 28, 639-667. [CrossRef]

13. Zeidler, D.L. Socioscientific Issues as a Curriculum Emphasis: Theory, Research, and Practice. In Handbook of Research on Science Education; Lederman, N.G., Abell, S., Eds.; Routledge: New York, NY, USA, 2014; Volume 2, pp. 697-726.

14. Bermúdez, G.M.; Lindemann-Matthies, P. “What Matters Is Species Richness"—High School Students' Understanding of the Components of Biodiversity. Res. Sci. Educ. 2018, 1-29. [CrossRef]

15. Pfundt, H.; Duit, R. Bibliography. Students' Alternative Frameworks and Science Education. 2009. Available online: http://archiv.ipn.uni-kiel.de/stcse/ (accessed on 15 May 2019).

16. Butler, A.C.; Marsh, E.J.; Slavinsky, J.P.; Baraniuk, R.G. Integrating Cognitive Science and Technology Improves Learning in a STEM Classroom. Educ. Psychol. Rev. 2014, 26, 331-340. [CrossRef]

17. Huxster, J.K.; Uribe-Zarain, X.; Kempton, W. Undergraduate Understanding of Climate Change: The Influences of College Major and Environmental Group Membership on Survey Knowledge Scores. J. Environ. Educ. 2015, 46, 149-165. [CrossRef]

18. Tompo, B.; Ahmad, A.; Muris, M. The development of discovery-inquiry learning model to reduce the science misconceptions of junior high school students. Int. J. Environ. Sci Educ. 2016, 11, 5676-5686. Available online: https://files.eric.ed.gov/fulltext/EJ1115682.pdf (accessed on 4 June 2020).

19. Jiménez-Liso, M.R.; Delgado, L.; Castillo-Hernández, F.J.; Banos-González, I. Contexto, indagación y modelización para movilizar explicaciones del alumnado de secundaria. Ensen. Cienc. 2020, in press.

20. Evagorou, M.; Puig Mauriz, B. Engaging Elementary School Pre-service Teachers in Modeling a Socioscientific Issue as a Way to Help Them Appreciate the Social Aspects of Science. Int. J. Educ. Math. Sci. Technol. 2016, 5, 113. [CrossRef] 
21. Bayram-Jacobs, D.; Henze, I.; Evagorou, M.; Shwartz, Y.; Leirvoll-Aschim, E.; Alcaraz-Domínguez, S.; Barajas, M.; Dagan, E. Science teachers' pedagogical content knowledge development during enactment of socioscientific curriculum materials. J. Res. Sci. Teach. 2019, 56, 1207-1233. [CrossRef]

22. Sandler, T.D. Socio-scientific Issues-Based Education: What We Know about Science Education in the Context of SSI. In Contemporary Trends and Issues in Science Education; Sadler, T., Ed.; Springer: Dordrecht, The Netherlands, 2011; Volume 39, pp. 355-369. [CrossRef]

23. Simonneaux, L.; Simonneaux, J. Students' socio-scientific reasoning on controversies from the viewpoint of education for sustainable development. Cult. Stud. Sci. Educ. 2009, 4, 657-687. [CrossRef]

24. España, E.; Reis, P. El proyecto We Act como marco para formar ciudadanos competentes a través del activismo colectivo basado en la investigación. Rev. Investig. Exp. Didact. 2017, extra, 657-662.

25. Palmberg, I.; Hofman-Bergholm, M.; Jeronen, E.; Yli-Panula, E. Systems thinking for understanding sustainability? Nordic student teachers' views on the relationship between species identification, biodiversity and sustainable development. Educ. Sci. 2017, 7, 72. [CrossRef]

26. Mascia, M.B. The human dimension of coral reef marine protected areas: Recent social science research and its policy implications. Conserv. Biol. 2003, 17, 630-632. [CrossRef]

27. Cinner, J.E.; McClanahan, T.R.; MacNeil, M.A.; Graham, N.A.J.; Daw, T.M.; Mukminin, A.; Feary, D.A.; Rabearisoa, A.L.; Wamukota, A.; Jiddawi, N.; et al. Comanagement of coral reef social-ecologicalsystems. Proc. Nat. Acad. Sci. USA 2012, 109, 5219-5222. [CrossRef]

28. Darling, E.S.; McClanahan, T.R.; Maina, J.; Gurney, G.G.; Graham, N.A.J.; Januchowski-Hartley, F.A.; Cinner, J.E.; Mora, C.; Hicks, C.C.; Maire, E.; et al. Social-environmental drivers inform strategic management of coral reefs in the Anthropocene. Nat. Ecol. Evol. 2019, 3, 1341-1350. [CrossRef] [PubMed]

29. Brody, M.J. Student science knowledge related to ecological crises. Int. J. Sci. Educ. 1994, 16, 421-435. [CrossRef]

30. Fauville, G. Questions as indicators of ocean literacy: Students' online asynchronous discussion with a marine scientist. Int. J. Sci. Educ. 2017, 39, 2151-2170. [CrossRef]

31. Sale, P. Our Dying Planet. An. Ecologist's View of the Crisis We Face; University of California Press: Berkeley, CA, USA; Los Angeles, CA, USA, 2011.

32. UN. The 2030 Agenda for Sustainable Development. Available online: https://sustainabledevelopment.un.org/ (accessed on 30 January 2020).

33. Jiménez-Liso, M.R.; Martínez Chico, M.; Avraamidou, L.; López-Gay, R. Scientific Practices in Teacher Education: The interplay of sense, sensors, and emotions. Res. Sci. Technol. Educ. 2019, 1-24. [CrossRef]

34. Dimopoulos, K.; Koulaidis, V. Science and Technology Education for Citizenship: The Potential Role of the Press. Sci. Educ. 2003, 87, 241-256. [CrossRef]

35. Diaz-Moreno, N.; Jiménez-Liso, M.R. Searching for Socioscientific Issues in the press and how often they appear. In Science education research: Engaging learners for a sustainable future (Electronic Proceedings of ESERA 2015); Lavonen, J., Juuti, K., Lampiselkä., J., Uitto, A., Hahl, K., Eds.; University of Helsinki: Helsinki, Finland, 2016; p. 1125. Available online: https://www.dropbox.com/sh/wmikjooeskc5uu2/AAD73aWkeVtVNQvFqLByWJeDa?dl= 0\&preview=eBook2015_Part_8_links.pdf (accessed on 2 March 2020).

36. Kang, J.; Keinonen, T. The Effect of Student-Centered Approaches on Students' Interest and Achievement in Science: Relevant Topic-Based, Open and Guided Inquiry-Based, and Discussion-Based Approaches. Res. Sci. Educ. 2017, 4, 1-21. [CrossRef]

37. Villnow, V.; Rombach, M.; Bitsch, V. Examining German media coverage of the re-evaluation of glyphosate. Sustainability 2019, 11, 1910. [CrossRef]

38. Noga, J.; Wolbring, G. An analysis of the united nations conference on sustainable development (Rio +20$)$ discourse using an ability expectation lens. Sustainability 2013, 5, 3615-3639. [CrossRef]

39. Jiménez-Liso, M.R.; Perales-Palacios, F.J.; Lara-Vargas, I. La mina de Aznalcóllar en Twitter años después del vertido: ¿controversia socioambiental espontánea o inducida? Estud. Sobre Mensaje Periodís. 2019, 25, 1485-1498. [CrossRef]

40. Lewenstein, B.V. Identifying what matters: Science education, science communication, and democracy. J. Res. Sci. Teach. 2015, 52, 253-262. [CrossRef] 
41. Reis, P.; Tinoca, L.; Baptista, M.; Linhares, E. The Impact of Student-Curated Exhibitions about Socio-Scientific Issues on Students' Perceptions Regarding Their Competences and the Science Classes. Sustainability 2020, 12, 2796. [CrossRef]

42. Oliveras, B.; Márquez, C.; Sanmartí, N. The Use of Newspaper Articles as a Tool to Develop Critical Thinking in Science Classes. Int. J. Sci. Educ. 2013, 35, 885-905. [CrossRef]

43. Domenech, J. Apuntes lingüísticos para el tránsito a la competencia científica. Didacticae 2019, 5, 85-98. [CrossRef]

44. Domènech-Casal, J. Propuesta de un marco para la secuenciación didáctica de Controversias Socio-Científicas. Estudio con dos actividades alrededor de la genética. Rev. Eurekasobre 2017, 14, 601-620. [CrossRef]

45. Moraga, S.H.; Espinet, M.; Merino, C.G. El contexto en la enseñanza de la química: Análisis de secuencias de enseñanza y aprendizaje diseñadas por profesores de ciencias en formación inicial. Rev. Eurekasobre 2019, 16, 1604. [CrossRef]

46. Marchán-Carvajal, I.; Sanmartí, N. Criterios para el diseño de unidades didácticas contextualizadas: Aplicación al aprendizaje de un modelo teórico para la estructura atómica. Educ. Quím. 2015, 26, 267-274. [CrossRef]

47. Lupión-Cobos, T.; López-Castilla, R.; Blanco-López, Á. What do science teachers think about developing scientific competences through context-based teaching? A case study. Int. J. Sci. Educ. 2017, 39, 937-963. [CrossRef]

48. Bartz, W.R. Teaching skepticism via the CRITIC acronym and the Skeptical Inquirer. Skept. Inq. 2002, 26, $42-44$.

49. Jarman, R. Developing Scientific Literacy: Using News Media in the Classroom; Open University Press-McGraw-Hill Education: Berkshire, UK, 2007.

50. McClune, B.; Jarman, R. Encouraging and equipping students to engage critically with science in the news: What can we learn from the literature? Stud. Sci. Educ. 2012, 48, 1-49. [CrossRef]

51. Nielsen, J.A.; Evagorou, M.; Dillon, J. New Perspectives for Addressing Socioscientific Issues in Teacher Education. In Science Teacher Education for Responsible Citizenship; Evagorou, M., Nielsen, J., Dillon, J., Eds.; Springer International Publishing: Cham, Switzerland, 2020; Volume 52, pp. 193-199. [CrossRef]

52. Garrido, A.; Couso, D. Introducing Model-Based Instruction for SSI Teaching in Primary Pre-service Teacher Education. In Science Teacher Education for Responsible Citizenship; Evagorou, M., Nielsen, J., Dillon, J., Eds.; Springer International Publishing: Cham, Switzerland, 2020; Volume 52, pp. 153-171. [CrossRef]

53. Jiménez-Aleixandre, M.P.; Erduran, S. Argumentation in Science Education; Springer: Dordrecht, The Netherlands, 2007. [CrossRef]

54. Osborne, J. Teaching Scientific Practices: Meeting the Challenge of Change. J. Sci. Teach. Educ. 2014, 25, 177-196. [CrossRef]

55. Shepardson, D.P.; Niyogi, D.; Roychoudhury, A.; Hirsch, A. Conceptualizing climate change in the context of a climate system: Implications for climate and environmental education. Environ. Educ. Res. 2012, 18, 323-352. [CrossRef]

56. Stevenson, K.T.; Peterson, M.N.; Bondell, H.D. The influence of personal beliefs, friends, and family in building climate change concern among adolescents. Environ. Educ. Res. 2019, 25, 832-845. [CrossRef]

57. Meira, P.Á. Problemas ambientales globales y educación ambiental: Una aproximación desde las representaciones sociales del cambio climático. Rev. Int. Educ. 2013, 6, 29-64. Available online: http://www. scielo.org.bo/scielo.php?script=sci_arttext\&pid=S1997-40432013000300003\&lng=es\&nrm=iso (accessed on 10 May 2020).

58. Esteve, P.; Jaén, M. El papel de los ciclos biogeoquímicos en el estudio de los problemas ambientales en Educación Secundaria. Rev. Investig. Esc. 2013, 80, 77-88.

59. McNeal, K.S.; Libarkin, J.C.; Ledley, T.S.; Bardar, E.; Haddad, N.; Ellins, K.; Dutta, S. The role of research in online curriculum development: The case of EarthLabs climate change and Earth system modules. J. Geosci. Educ. 2014, 62, 560-577. [CrossRef]

60. Danielson, K.I.; Tanner, K.D. Investigating undergraduate science students' conceptions and misconceptions of ocean acidification. CBE Life Sci. Educ. 2015, 14, ar29. [CrossRef]

61. Daniel, B.; Stanisstreet, M.; Boyes, E. How can we best reduce global warming? School students' ideas and misconceptions. Int. J. Environ. Stud. 2004, 61, 211-222. [CrossRef] 
62. González-Weil, C.; Harms, U. From Tree to Chloroplast: K-9 and K-10 students' conceptions about «living being» and «cell». Ensen. Cienc. 2012, 30, 31-52. [CrossRef]

63. Velasco, J.M. ¿Cúando un ser vivo puede ser considerado animal? Ensen. Cienc. 1991, 9, 43-52.

64. Caballer, M.J.; Giménez, I. Las ideas de los alumnos y alumnas acerca de la estructura celular de los seres vivos. Ensen. Cienc. 1992, 10, 172-180.

65. Caballer, M.J.; Giménez, I. Las ideas del alumnado sobre el concepto de célula al finalizar la educación general básica. Ensen. Cienc. 1993, 11, 63-68.

66. Caravita, S.; Falchetti, E. Are bones alive? J. Biol. Educ. 2005, 39, 163-170. [CrossRef]

67. Yost, R.W.; Gonzalez, E.L.F. A coral reef as an analogical model to promote collaborative learning on cultural \& ethnic diversity in science. Am. Biol. Teach. 2008, 70, 39-43. [CrossRef]

68. Lambert, J.L.; Lindgren, J.; Bleicher, R. Assessing elementary science methods students' understanding about global climate change. Int. J. Sci. Educ. 2012, 34, 1167-1187. [CrossRef]

69. Shepardson, D.P.; Niyogi, D.; Choi, S.; Charusombat, U. Students' conceptions about the greenhouse effect, global warming, and climate change. Clim. Chang. 2011, 104, 481-507. [CrossRef]

70. Jarrett, L.; Takacs, G. Secondary students' ideas about scientific concepts underlying climate change. Environ. Educ. Res. 2020, 26, 400-420. [CrossRef]

71. Howard, K.E.; Brown, S.A.; Chung, S.H.; Jobson, B.T.; Vanreken, T.M. College students' understanding of atmospheric ozone formation. Chem. Educ. Res. Pract. 2013, 14, 51-61. [CrossRef]

72. Menzel, S.; Bögeholz, S. The loss of biodiversity as a challenge for sustainable development: How do pupils in Chile and Germany perceive resource dilemmas? Res. Sci. Educ. 2009, 39, 429-447. [CrossRef]

73. Ergazaki, M.; Ampatzidis, G. Students' reasoning about the future of disturbed or protected ecosystems \& the idea of the 'balance of nature'. Res. Sci. Educ. 2012, 42, 511-530. [CrossRef]

74. Oliva, J.M. Distintas acepciones para la idea de modelización en la enseñanza de las ciencias. Ensen. Cienc. 2019, 37, 5-24. [CrossRef]

75. Garrido, A.; Couso, D. Models and Modelling as a Training Context: What are Pre-service Teachers' Perceptions? In Proceedings of the Bi-Annual Meeting of the European Science Education Research Association (ESERA), Dublin, Ireland, 21-25 August 2017.

76. Mostafa, T.; Echazarra, A.; Gillou, H. The science of teaching science practices in PISA 2015. In OECD Education Working Papers No. 188; OECD Publishing: Paris, France, 2018. [CrossRef]

77. Romero-Ariza, M. El aprendizaje por indagación: ¿existen suficientes evidencias sobres sus beneficios en la enseñanza de las ciencias? Rev. Eurekasobre 2017, 14, 286-299. [CrossRef]

78. Aguilera, D.; Perales-Palacios, F.J. What Effects Do Didactic Interventions Have on Students' Attitudes Towards Science? A Meta-Analysis. Res. Sci. Educ. 2018, 1-25. [CrossRef]

79. Abd-El-Khalick, F.; Boujaoude, S.; Duschl, R.; Lederman, N.G.; Mamlok-Naaman, R.; Hofstein, A.; Niaz, M.; Treagust, D.; Tuan, H.L. Inquiry in science education: International perspectives. Sci. Educ. 2004, 88, 397-419. [CrossRef]

80. Lazonder, A.W.; Harmsen, R. Meta-Analysis of Inquiry-Based Learning Effects of Guidance. Rev. Educ. Res. 2016, 86, 681-718. [CrossRef]

81. Jerrim, J.; Oliver, M.; Sims, S. The relationship between inquiry-based teaching and students' achievement. New evidence from a longitudinal PISA study in England. Learn. Instr. 2019, 61, 35-44. [CrossRef]

82. Minner, D.D.; Levy, A.J.; Century, J. Inquiry-based science instruction-What is it and does it matter? Results from a research synthesis years 1984 to 2002. J. Res. Sci. Teach. 2010, 47, 474-496. [CrossRef]

83. Inkinen, J.; Klager, C.; Juuti, K.; Schneider, B.; Salmela-Aro, K.; Krajcik, J.; Lavonen, J. High school students' situational engagement associated with scientific practices in designed science learning situations. Sci. Educ. 2020, 104, 667-692. [CrossRef]

84. Fang, S.C.; Hsu, Y.S.; Chang, H.Y.; Chang, W.H.; Wu, H.K.; Chen, C.M. Investigating the effects of structured and guided inquiry on students' development of conceptual knowledge and inquiry abilities: A case study in Taiwan. Int. J. Sci. Educ. 2016, 38, 1945-1971. [CrossRef]

85. Hernández, M.I.; Couso, D.; Pintó, R. Analyzing Students' Learning Progressions Throughout a Teaching Sequence on Acoustic Properties of Materials with a Model-Based Inquiry Approach. J. Sci. Educ. Technol. 2015, 24, 356-377. [CrossRef]

86. Doymus, K.; Karacop, A.; Simsek, U. Effects of jigsaw and animation techniques on students' understanding of concepts and subjects in electrochemistry. Educ. Technol. Res. Dev. 2010, 58, 671-691. [CrossRef] 
87. Corals Reproduction. Available online: https://www.youtube.com/watch?v=5m YyYm99QAc (accessed on 21 February 2020).

88. Ochoa de Alda, J.A.G.; Marcos-Merino, J.M.; Méndez Gómez, F.J.; Mellado Jiménez, V.; Esteban Gallego, M.R. Emociones académicas y aprendizaje de biología, una asociación duradera. Ensen. Cienc. 2019, 37, 43-61. [CrossRef]

89. McMillan, J.H.; Schumacher, S. Research in Education: Evidence-Based Inquiry. In MyEducationLab Series; Pearson: London, UK, 2010; p. 528.

90. Bevins, S.; Price, G. Reconceptualising inquiry in science education. Int. J. Sci. Educ. 2016, 38, 17-29. [CrossRef]

91. Martínez-Chico, M.; Jiménez-Liso, M.R.; Evagorou, M. Design of a pre-service teacher training unit to promote scientific practices. Is a chickpea a living being? Int. J. Des. Learn. 2020, 11, 21-30. [CrossRef]

92. Alsop, S.; Watts, M. Science education and affect. Int. J. Sci. Educ. 2003, 25, 1043-1047. [CrossRef]

93. Nicolaou, C.T.; Evagorou, M.; Lymbouridou, C. Elementary School Students' Emotions When Exploring an Authentic Socio-Scientific Issue through the Use of Models. Sci. Educ. Int. 2015, 26, 240-259.

94. Osborne, J.; Dillon, J. Science Education in Europe: Critical Reflections; The Nuffield Foundation: London, UK, 2008; pp. 1-32.

95. Guisasola, J.; Zuza, K.; Ametller, J.; Gutierrez-Berraondo, J. Evaluating and redesigning teaching learning sequences at the introductory physics level. Phys. Rev. Phys. Educ. Res. 2017, 13, 020139. [CrossRef]

96. Otto, S.; Pensini, P. Nature-based environmental education of children: Environmental knowledge and connectedness to nature, together, are related to ecological behaviour. Glob. Environ. Chang. 2017, 47, 88-94. [CrossRef]

97. Stoll-Kleemann, S.; Schmidt, U.J. Reducing meat consumption in developed and transition countries to counter climate change and biodiversity loss: A review of influence factors. Reg. Environ. Chang. 2017, 17, 1261-1277. [CrossRef]

98. Varela-Losada, M.; Arias-Correa, A.; Pérez-Rodríguez, U.; Vega-Marcote, P. How Can Teachers Be Encouraged to Commit to Sustainability? Evaluation of a Teacher-Training Experience in Spain. Sustainability 2019, 11, 4309. [CrossRef]

99. Aarnio-Linnanvuori, E. How do teachers perceive environmental responsibility? Environ. Educ. Res. 2019, 25, 46-61. [CrossRef] 